\title{
The Vowel System of Korebaju
}

\author{
Jenifer Vega Rodríguez \\ Université Sorbonne Nouvelle - Paris, France \\ Jenifer.vega-rodriguez@sorbonne-nouvelle.fr
}

\begin{abstract}
Korebaju [kòrèßáhì] (ISO 639-3: coe) is a Western Tukanoan language from the South-Western part of Colombia. A study conducted in 2017 and 2018 with six native speakers (3 female and 3 male) shows that Korebaju has an inventory of 17 consonants $/ \mathrm{p}, \mathrm{t}, \mathrm{k}, \mathrm{p}^{\mathrm{h}}, \mathrm{t}^{\mathrm{h}}, \mathrm{k}^{\mathrm{h}}, \beta, \phi, \mathrm{s}, \mathrm{h}, \widehat{\mathrm{t}} \int, \mathrm{m}, \mathrm{n}, \mathrm{n},{ }^{\mathrm{h}} \mathrm{m},{ }^{\mathrm{h}} \mathrm{y}$, $\mathrm{r} /$ and 6 oral vowels $/ \mathrm{i}, \mathrm{e}, \mathrm{a}, \mathrm{o}, \mathrm{u}, \mathrm{i} /, 6$ nasal vowels $/ \tilde{1}$, ẽ, ã, õ, $\tilde{\mathrm{u}}, \tilde{\mathrm{t}} /$ and 3 glottal vowels $/ \mathrm{a}^{2}, \mathrm{e}^{2}, \mathrm{o}^{2} /$. Contrary to previous studies, this paper shows that Korebaju does not include the vowel [u] in its phonemic inventory. The vowel [u] is an allophone of the high back vowel /u/ when it follows a palatal consonant. In the same context, the high central vowel /i/ also has an allophone [I]. This paper focuses on an acoustic and articulatory description. Data come from a set of words recorded with synchronized audio and EGG signals.

Index Terms: Acoustic and articulatory phonetics, glottal features, language description.
\end{abstract}

\section{Introduction}

Korebaju [kòrèßàhí] (often transcribed as Koreguaje), is a Western Tukanoan language spoken in Colombia along the banks of the Orteguaza, Consaya and Peneya rivers, located in the foothills of the Amazon. This community is today, a result of the union of four different communities: Korebaju, Tama, Carijona and Macaguaje. All members of the community speak Korebaju. Most other languages have gone extinct except for Carijona which is still spoken in another region of Colombia. Consequently, there are dialectical variations in Korebaju. Dialectical variations are contained within specific parts of the community and they are, therefore, clearly distinguished. To avoid the influence from one or more of these dialectical variations, this study draws its participants from one Korebaju village where members are of korebaju descent and have very little contact with the other parts of the community.

The existent literature on the Korebaju language is short and inconclusive. There are only three studies that have attempted to describe the phonological inventory of the Korebaju language. Dupont (manuscript) proposes an inventory of 10 consonants $/ \mathrm{p}, \mathrm{t}, \mathrm{k}, \mathrm{b}, \mathrm{d}, \mathrm{g}, \mathrm{c}, \mathrm{j}, \mathrm{s}, \mathrm{h} /$ and 6 vowels $/ \mathrm{i}, \mathrm{e}, \mathrm{a}, \mathrm{o}, \mathrm{u}, \mathrm{u} /$. Additionally, he advances a theory that would suggest suprasegmental nasalization based on phonological patterns like nasal harmony, and glottalization based on suprasegmental rules. Dupont also categorizes the language as tonal with two phonological tones (high and low) and a phonetic falling [ ${ }^{\wedge}$ ] tone. Herrera (1990) proposes an inventory of 14 consonants $/ \mathrm{p}, \mathrm{t}, \mathrm{k}, \phi, \beta, \mathrm{s}, \mathrm{h}, \mathrm{t} f, \mathrm{~m}, \mathrm{n}, \mathrm{n}$, mh, nh, r/ and 12 vowels /i, e, a, o, u, u, ĩ, ẽ, ã, õ, ũ, ũ/. The third representation is done by Cook \& Criswell (1993) suggesting an inventory of 24 consonants $/ \mathrm{p}, \mathrm{t}, \mathrm{k}, \mathrm{p}^{\mathrm{h}}, \mathrm{t}^{\mathrm{h}}, \mathrm{k}^{\mathrm{h}}, \mathrm{k}^{\mathrm{w}}$, $\mathrm{t}^{\text {hw }}, \mathrm{k}^{\mathrm{hw}}$, ?, W, w, s, sw $, \mathrm{h}, \breve{\mathrm{j}}, \breve{\jmath}^{\mathrm{w}}, \mathrm{m}, \mathrm{n}, \tilde{\mathrm{n}}, \mathrm{m}, \tilde{\mathrm{n}}, \mathrm{r}, \mathrm{r}^{\mathrm{w}} /, 6$ vowels $/ \mathrm{i}$, $\mathrm{e}, \mathrm{a}, \mathrm{o}, \mathrm{u}, \dot{\mathrm{i}} / \mathrm{with}$ suprasegmental nasalization, two phonological tones (high and low) and stress on the first syllable (Grallow, 1985).

This study will attempt to describe the vowel system of Korebaju by analyzing acoustical and articulatory data. Variability in the representations of Korebaju's phonological inventory show disagreement regarding the phonological status of the high-central-unrounded vowel [i] and high back unrounded vowel [u]. Another question that arises when looking at the existing literature is whether glottalization is a suprasegmental feature of the language or a segmental glottal stop. This also raises the question of whether nasalisation should be treated as a suprasegmental feature or segmental phoneme.

Glottal vowels have been found and described in different languages of the world. In Colombia, glottal vowels were found in Nasa Yuwe where "the glottal character of the vowels appear during the vowels with a contribution of the ventricular folds with a complete closure at the end" Demolin at al. (2016).

Finally, glottalization is treated as a suprasegmental feature in some languages of Tukanoan family, this is the case for Wanano where Stenzel (2007) proposes a [constrictive glottal] feature of the syllabic attack. However, Korebaju implements selective glottalization to generate minimal pairs present in the language.

\section{Method}

\subsection{Participants}

Six native speakers (three female and three male) participated in the study. All the participants are native speakers of Korebaju, were from the village in which the study was conducted and attested to being of Korebaju descent. The participants also spoke Spanish. Local law mandates that students start learning Spanish at the age of nine/ten at the secondary school. Participants were between 25 and 58 years old at the time the study took place. The participants are distributed as follows: Female 1: 28; Female 2: 22; Female 3: 56; Male 1: 29; Male 2: 24; Male 3: 58. 

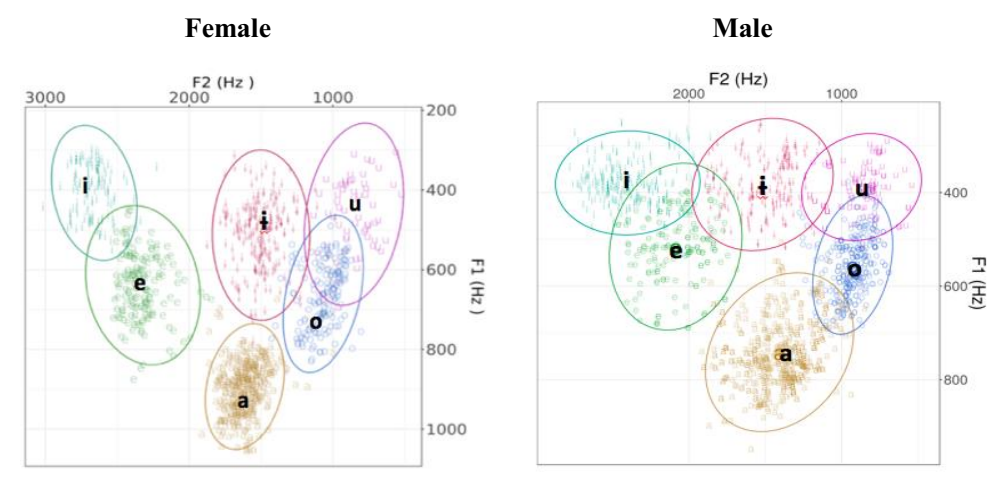

Figure 1: F1/F2 distribution of the 6 oral vowels produced by 3 female and 3 male

\subsection{Materials}

Acoustic data were recorded using a Zoom H6 recorder and a Shure WH30 microphone. The same microphone was used for the synchronized acoustic and electro-glottograph data. To collect glottal data, a Glottograph EG2-PC was connected to a Motu - Ultra Lite Mk3 Hybrid sound card. Recordings were done via Audacity. A solar panel served as the source of energy. Data were segmented using Sound Forge and analysed with Phonedit, Praat, and Winpitch software.

\subsection{Procedure}

A corpus of 275 words was created for the acoustic analysis. 182 words were recorded for the synchronized sound-EGG data. In both cases, each word is repeated three times by each speaker.

A carrier sentence was used to avoid variations and to place the word in a semi-authentic environment. Sentences produced by women and men were different in one morphological aspect as the indexicality of the language changes according to the speaker. The morpheme attaches to the verb root and it does not affect the rhythmic groups within the sentence. The phrases were constructed as follows:

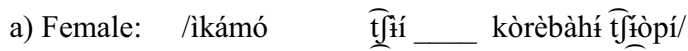 'I said in korebaju'

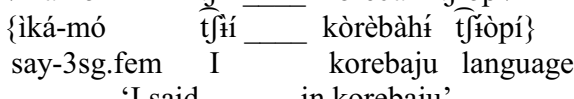

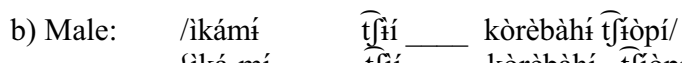

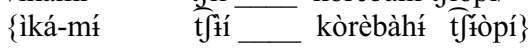 say-3sg.masc I korebaju language 'I said in korebaju'

\subsection{Data Analysis}

Each word was segmented manually into phones using Praat. The measure of formants, pitch and duration of modal vowels was done by using Praat scripts, followed up by manual verification of irregular values. For the contrast between glottal and modal vowels, the measure of duration was done under the assumption that glottalization was part of the vowel to see if a significant difference was found between the two vowels in the same context.

\section{Results}

\subsection{Oral vowels}

Six phonemic oral vowels $/ \mathrm{i}, \mathrm{e}, \mathrm{a}, \mathrm{o}, \mathrm{u}, \dot{\mathrm{i}} / \mathrm{w}$ were found in this study. In Figure 1 a Lobanov normalization was used to show vowel distribution between male and female speakers.

For analysis of the status of the high central unrounded vowel [i] and high back unrounded vowel [u] , the mean of each formant was measured for the full set of vowels, (see figure 2). The results show that the formants for the central vowel correspond to the close central unrounded vowel [i] described by Cook \& Criswell (1993).

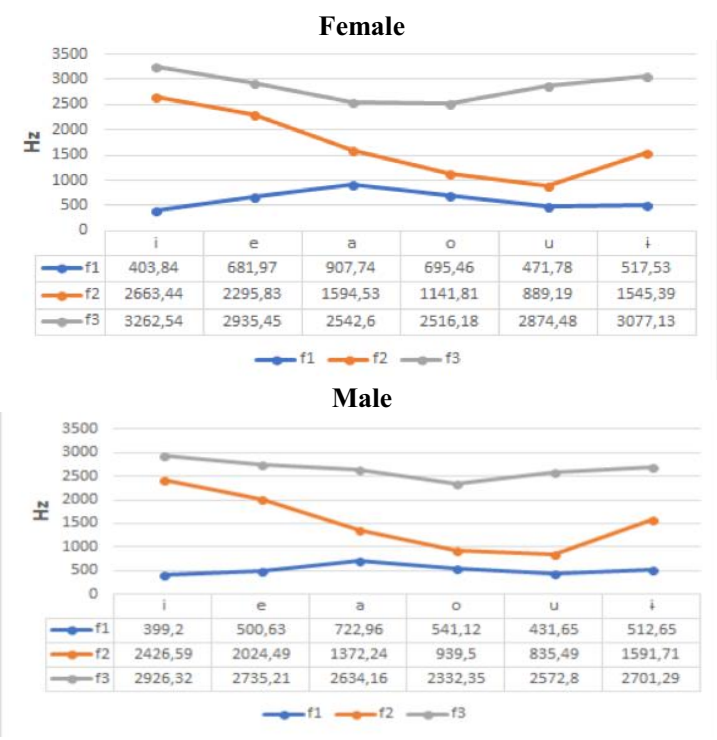

Figure 2: Mean F1/F2/F3 values for female and male speakers $(n=1099)$.

The following minimal pairs shows the contrast between the phonemic vowels.
a) /píá/
/píál

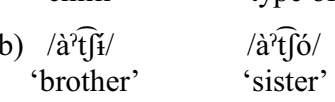




\subsection{Allophones}

This study found two different allophones. Figure 3 shows a vowel [u] which is an allophone of the high back vowel /u/ when it follows a palatal consonant. In the same context, the high central vowel/it/also has an allophone [I].

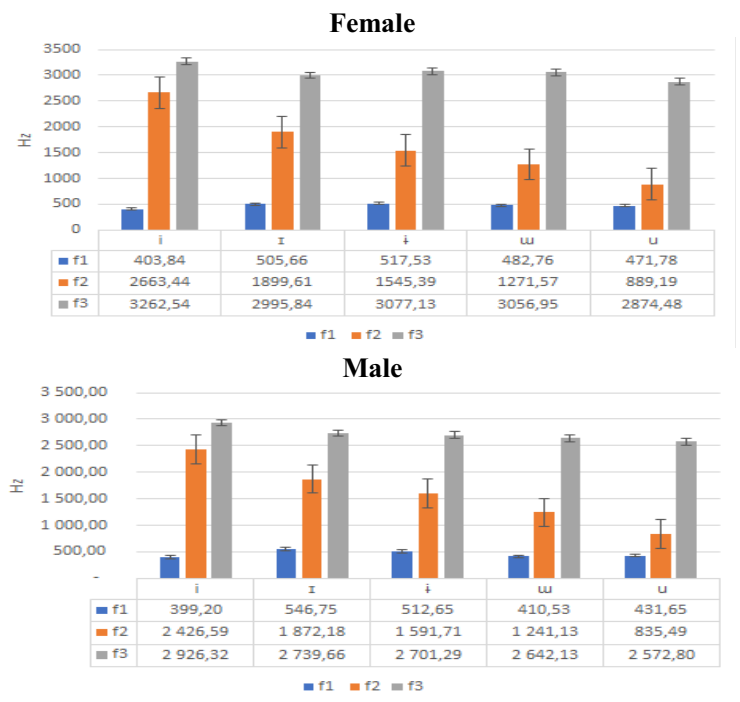

Figure 3: Mean of F1/F2/F3 values for the high vow else /it and $/ u /$ and its allophones pronounced by female and male speakers. $(n=248)$.

The following words show this allophony:
a) 'give me'

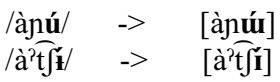
b) 'brother'
c) 'knife'

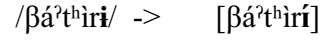

\subsection{Nasal vowels}

This study found a contrast between the full set of oral vowels /i, e, a, o, u, i/ and its corresponding nasal vowels /ĩ, ẽ, ã, õ, ũ, $\tilde{\mathbf{f}} /$ as shown in the following minimal pairs.

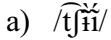
|tfyíl
'azulejo (type of bird)'
'coton'
b) / $/ \mathrm{t} \sqrt{\mathrm{g}} \mathrm{o} /$
'girl'
/t迆/
c) /ừhé/
' type of sardine'
'crop'
/ùhé/
'wild turkey'

Figure 4 shows the contrast between oral and nasal vowels with the same tonal pattern. [ț̂̀ió]

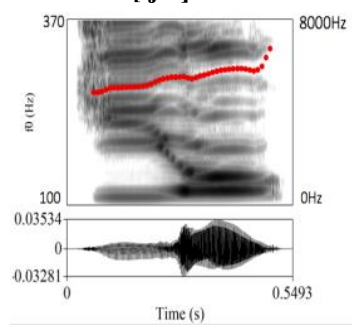

[t]站]

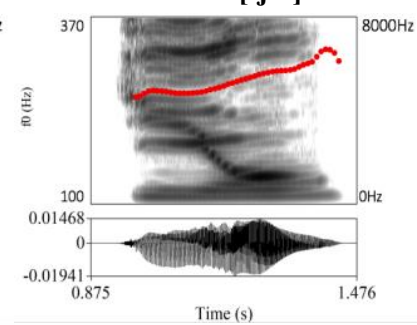

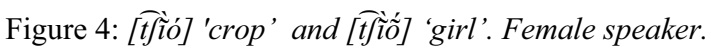

This study did not find nasal harmony in any of the fieldwork analyses.

\subsection{Glottal vowels}

The results of this study show three different realizations of glottal features. The first one shows a glottal constriction attached to a set of non-high vowels $/ a^{2}, e^{?}, o^{2} /$, these realizations are contrastive in the language as shown in the following minimal pairs or quasi-minimal pairs.

\begin{tabular}{|c|c|c|}
\hline a) & $\begin{array}{l}\text { /nàsé/ } \\
\text { 'toucan' }\end{array}$ & $\begin{array}{l}\text { /nà'sé/ } \\
\text { 'agujon' (type of fish) }\end{array}$ \\
\hline b) & $\begin{array}{l}\text { /\$èémì̀ / } \\
\text { 'to pop' }\end{array}$ & $\begin{array}{l}\text { /\$è’némì̀ / } \\
\text { 'lightning' }\end{array}$ \\
\hline c) & $\begin{array}{l}\text { 'k 'k òk'ómè̃̀)/ } \\
\text { 'he's getting wet' }\end{array}$ & $\begin{array}{l}/ k^{\text {hò̀ }}{ }^{\text {h }} \text { ómì̀ } / \\
\text { 'he coughs' }\end{array}$ \\
\hline
\end{tabular}

Figure 5 shows the contrast between the oral vowel /a/ and its correspondent glottal vowel $/ \mathrm{a}^{2} \%$.

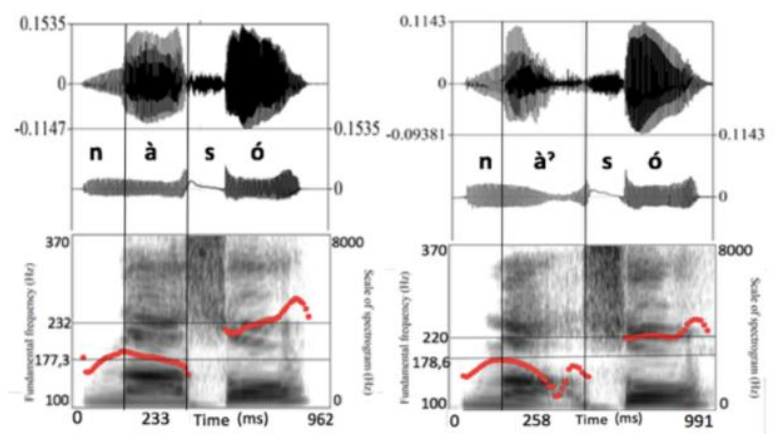

Figure 5: Sound, EGG and Spectrogram for words 'shrimp' [nà'só] and 'churuco (type of monkey)' [nàsó]. Male speaker.

Two other realisations are produced randomly by the speakers and the study did not show any contrast. One glottal stop [?] and one transition defined by Ladefoged \& Maddieson (1996) as creaky-voiced glottal approximant $\left[{ }^{*}\right]$ occur between two vowels. In both cases, this is interpreted as a [constrictive glottal] suprasegmental feature, following the analyses done by Stenzel (2007) for Wanano, another Tukanoan language.

\section{Discussion}

This study confirms the phonemic status of the set of oral vowels /i, e, a, o, u, i/ described by Cook \& Criswell (1993). The status of the central vowel /i/ was confirmed by measuring its formants (figure 2), showing that the second formant (F2) has a mean of approximately $1500 \mathrm{~Hz}$ which corresponds to the values of an unrounded central vowel. By looking at the third formant (3), we confirm the absence of a rounded feature in this vowel. With a value of around $3000 \mathrm{~Hz}$, and in comparison, to the third formant value of the rest of the vowels, we can see that its value is superior to the mean of the rounded vowels $/ \mathrm{o}, \mathrm{u} /$. 

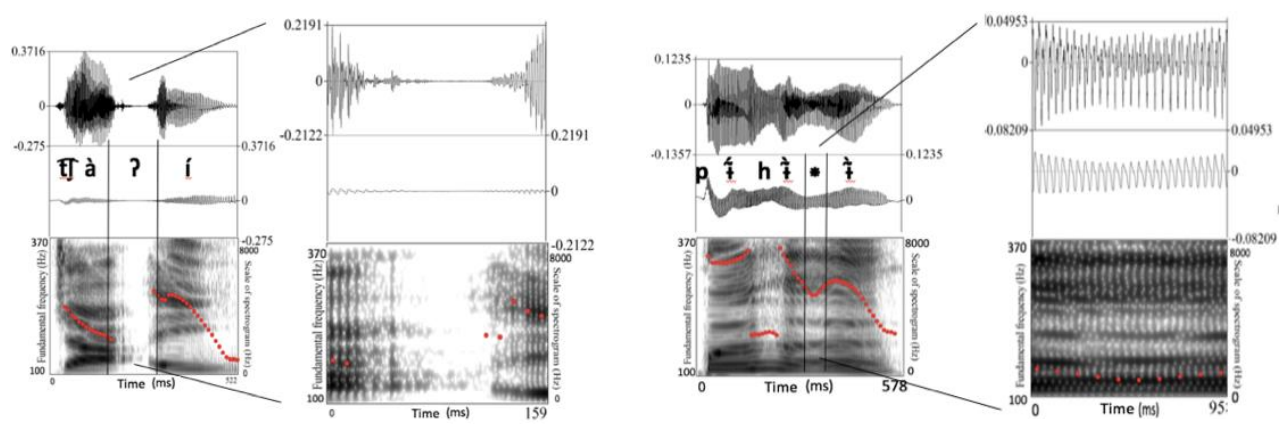

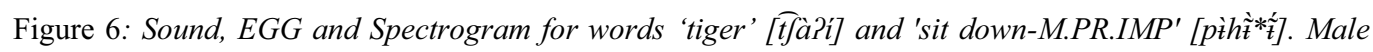

This set of oral vowels coincides with the oral vowel set proposed for Proto-Tukano described by Chacon (2014).

The phone $[\mathrm{w}]$ described as a phoneme in previews analyses was found to be an allophone for the vowel $/ \mathrm{u} /$ after a palatal consonant. The same phenomenon is reproduced in the case of the phoneme [I] as an allophone of the vowel $/ \mathbf{i} /$. Figure 3 shows the progressives rise of $\mathrm{f} 2$ for the set of high vowels and its allophones, showing that there is anteriorization of the vowel related to palatal contexts. These allophones were not described in previous analyses.

This study shows the phonological status of nasal vowels /ĩ, ẽ, ã, õ, ũ, $\tilde{\mathrm{f}} /$ by contrasting this set with the set of oral vowels. Data did not show any features of nasal harmony.

This study also shows contrast between non-high glottal $/ \mathrm{a}^{2}, \mathrm{e}^{2}, \mathrm{o}^{2} /$ and oral vowels $/ \mathrm{a}, \mathrm{e}, \mathrm{o} / . \quad$ Figure 7 shows the duration of each glottal vowel in contrast with its correspondent oral vowel. An ANOVA test showed that the duration between vowels is not significant. We followed the analysis with a Bonferroni test which showed that difference in duration was not significant between vowel pairs.

\section{Female}
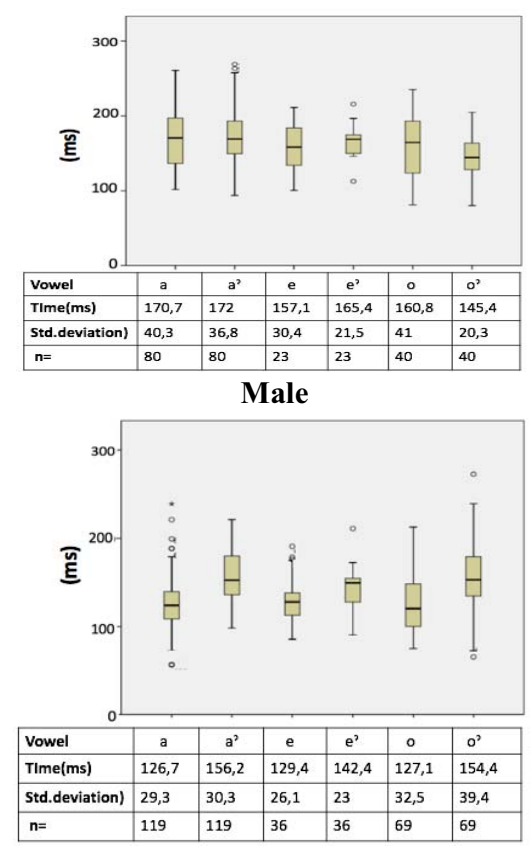

Figure 7: Male and Female length of glottal and oral vowels.
Finally, this study found a random occurrence of a glottal stop [?] and a creaky-voiced glottal approximant [*] between two vowels (Figure 6) amongst the speakers. These two occurrences demonstrate a difference between glottal vowels $/ \mathrm{a}^{2}, \mathrm{e}^{\mathrm{P}}, \mathrm{o}^{\mathrm{P}} /$ and modal vowels $/ \mathrm{a}, \mathrm{e}, \mathrm{o} /$ which are contrastive in Korebaju.

This study did not find any intervocalic glottal contrasts within any other Tukanoan language. We therefore propose a [constrictive glottal] feature that represents a syllabic attack following Stenzel's study (2007).

\section{Conclusions}

This study proposes a vowel system consisting of 15 vowels, 6

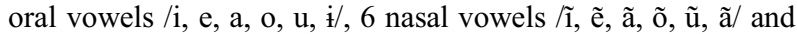
three glottal vowels $/ \mathrm{a}^{\text {? }}, \mathrm{e}^{\text {? }}, \mathrm{o}^{\text {? }}$.

This study also shows that Korebaju does not have a high back unrounded vowel [u] in its phonemic inventory. However, this vowel was found to be an allophone of the high back rounded vowel $/ \mathrm{u} /$ as well as the near-close-near-frontunrounded vowel $[\mathrm{I}]$ which is an allophone of the high-frontunrounded vowel $/ \mathbf{i} /$, where it's follow by a palatal consonant.

Data shows the contrast between the full set of oral vowels $/ i$, e, a, o, u, í / with its correspondent nasal vowels /ĩ, ẽ, ã, õ, ũ, $\tilde{\mathbf{i}} /$.

Finally, this study found different glottal features in Korebaju. The first one is a glottalization at the end of the vowel describe by Demolin at al. (2016) as a glottal vowel $/ \mathrm{V} /$. These vowels correspond to the set of no-high vowels $/ \mathrm{a}^{\text {? }}$, $\mathrm{e}^{\mathrm{z}}, \mathrm{o}^{\mathrm{p} /}$ and they contrast with their corresponding oral vowels /a, e, o/.

Contrary to previous descriptions of the language, a glottal stop [?] and a creaky-voiced glottal approximant represented by Ladefoged \& Maddieson (1996) as [*] occurs between two vowels. In both cases, they are interpreted as a [glottal constrictive] suprasegmental feature, following the analyses done by Stenzel (2007) for Wanano. It should be specified that these productions are not contrastive in the language. This description is similar to the one proposed by Gefen (2005) for Coatzospan Mixtec. 


\section{References}

[1] Chacon, Thiago. (2014). A Revised proposal of Proto-Tukanoan consonants and Tukanoan family classification. International Journal of American Linguistics 80(3). 275 -322.

[2] Cristancho Botia, M.D.; García Moreno, N.B. (1982). Aspectos Fonológicos De La Lengua Coreguaje (mémoire de licence). Universidad Nacional de Colombia, Bogotá, Colombia.

[3] Cook, D. et Criswell, L. (1993). El idioma Koreguaje (tukano occidental) Bogotá. SIL.

[4] Demolin, D., Amelot, A., Crevier-Buchman, L., and Rojas Curieux, T. (21016) The vowel system of Nasa Yuwe. Acoustical Society of America, Utah, United States. 140 (4), pp.3106, The Journal of the Acoustical Society of America.

[5] Dupont, C. (Unpublished Manuscript) La Langue Koreguaje (tukano Occidental). Phonologie et Morphologie.

[6] Gerfen, C. (2005). The production and perception of laryngealized vowels in Coatzospan Mixtec. Journal of Phonetics 33, p.331-334.

[7] Grallow, F. (1985) The coreguaje suprasegmentale system: tone, stress and intonation. En Phonology to discurs: Studies in six Colombian languages, ed. Ruth. Brend. (Lenguaje Data, Amerindian series) 9. p. 3-11. Summer Institut of Linguistics. Dallas.

[8] Herrera Casimilas, G.E. (1990) Manual de pronunciación española para hablantes koreguajes basado en el análisis contrastivo a nivel fonológico de los dos idiomas (mémoire de licence). Universidad Nacional de Colombia, Bogotá, Colombia.

[9] Ladefoged, P., \& Maddieson, I. (1996) The sounds of the world's languages. Oxford: Blackwell Publishers.

[10] Stenzel, K. (2007). Glottalization and other suprasegmental features in Wanano. International Journal of American Linguistics, 73, 331-66 